\section{SOME ASPECTS OF INFANT FEEDING.}

BX J. C. DRUMMOND, D Sc.

ThERE are few problems of nutrition which arouse greater interest at the present time than those which relate to the feeding of infants. Our knowledge of the dietary requirements of the human organism has advanced so rapidly during the last decade that it has. led to abandonment of many beliefs and the modification of many fundamental theories. Such a theory was that which taught us that the food requirements of the animal body could be expressed in terms of what had for so long been regarded as the primary food units-the proteins, fats, carbohydrates, and inorganic salts.

It is unnecessary to review here the large amount of research work which has demonstrated the inaccuracy of this theory, for it is now generally accepted that these food units are in themselves insufficient to satisfy the requirements of the animal for growth and maintenance of health, and that there exist a number of indispensable dietary components which are not members of any of these four recognised classes of foodstuffs.

\section{Accessory Factors of the Diet.}

It is mainly as a result of the pioneer work of Hopkins ${ }^{1}$ in this country that research upon this subject has been stimulated so far that a stage has now been reached when we can almost claim to be able to define the fundamental dietary units. Animals fed upon a diet of pure protein, fat, carbohydrate, and inorganic salts rapidly decline in health and die within a comparatively short time unless they are provided with an adequate amount of certain other dietary factors. These substances received the name "vitamines" from Funk, but chiefly for the reason that this term is very misleading it is now being discarded. These substances are now referred to collectively as the accessory factors of the diet. So far the existence of three individual substances of this type has been detected. At least two of these are of primary importance for growth, whilst all three are undoubtedly necessary for the preservation of health.

The provisional and non-committal names which have been allotted to these factors are as follows: (1) Fatsoluble A"; (2) "Water-soluble B," or anti-beri-beri (antineuritic) factor ; and (3) "Water-soluble C," or antiscorbutic factor. As yet practically nothing is known of the chemical nature of any one of these substances.

The object of the present paper is to draw attention to the infuence of these factors on infant nutrition. Unfortunately, those interested in the science of infant feeding are only just beginning to appreciate the vital importance of these substances for growth, and one still encounters many misleading and inaccurate statements about them.

"Fat-soluble A" is synthesised by the plant and is found present in most green leaves and in the embryos of certain cereals. Such foodstuffs constitute the primary sources of the factor for the animal organism, which, apparently, does not possess the power to synthesise it. In the embryos of seeds this substance probably occurs in loose combination with protein, but when liberated, as it is during digestion, it shows similar solubilities to the fats and lipoids, and accompanies these substances during absorption. The growing animal demands a liberal supply of this factor, but we are ignorant as to the exact rôle it plays in the body. The adult can maintain good health upon a much smaller intake. Probably in both cases any excess of intake over and above the actual requirements for growth or tissue repair is stored in company with depôt fat. Young animals deprived of this factor in their diet usually show no ill effect for a little time, during which it is probable that they are drawing upon their reserve supplies to make good the deficiency. Sooner or later, however, growth ceases, and they exhibit a greatly impaired resistance to disease, which usually results in an early death from acnte infections, particularly of the lungs. Prompt correction of the inadequacy in the diet by the inclusion of some foodstuff containing an ample amount of the missing factor results in a more or less rapid recovery of health, and nltimately the resumption of a normal rate of growth.

The "water-soluble B" is probably identical with the dietary factor that has been termed the anti-beri-beri vitamine. $^{2}$ The diseases known as beri-beri and infantile beri-beri represent, however, the final pathological condition induced by a deficiency of this factor in the diet. Long before such syndromes appear the deficiency manifests itself in a retardation or inhibition of growth. Young animals show absolutely no growth when entirely deprived of this dietary unit, and it is only after this inhibition has been maintained for some time that the typical symptoms of nerve incoördination appear. The animal cannot synthesise "water-soluble B," and is therefore entirely dependent upon the plant kingdom for its supplies. Cereal embryos and yeast are the richest known sources amongst the natura! food stuffis.

The antiscorbutic factor, or, as we may now term it, "water-soluble C," is probably indispensable to all growing animals, although many species exhibit a very slight susceptibility to scurvy, and therefore require very small amounts of the protecting substance. As in the case of the factors " $A$ " and "B," the animal is primarily dependent upon the plant kingdom for the substance " $\mathrm{C}$," which chiefly occurs in fresh vegetables and fruits.

The following tables indicate the chief properties of the three substances, and give a short guide as to their distribution in natural foodstuffs :-

\section{TABLE $T$}

A - " Fat-soluble A." B = " Water-soluble B," or anti-beri-beri factor $\mathbf{C}=$ "Water-soluble C," or anti-scorbutic factor.

\begin{tabular}{|c|c|c|c|}
\hline- & A. & B. & c. \\
\hline $\begin{array}{l}\text { Stability to } \\
\text { temperature. }\end{array}$ & $\begin{array}{l}\text { S t a b le a t } \\
100^{\circ} \text { C., prob- } \\
\text { ably stable at } \\
140^{\circ} \text { C. }\end{array}$ & $\begin{array}{l}\text { Comparatively } \\
\text { stable at } 100^{\circ} \mathrm{C} . \\
\text { Slowlydestroyed } \\
\text { at } 120^{\circ} \mathrm{C} \text {. and } \\
\text { above. }\end{array}$ & $\begin{array}{l}\text { Gradually de- } \\
\text { stroyed above } \\
50^{\circ} \mathrm{C} \text {. Rapidly } \\
\text { destroyed above } \\
80^{\circ} \mathrm{C} \text {. }\end{array}$ \\
\hline $\begin{array}{l}\text { Stability to } \\
\text { alkalies. }\end{array}$ & $\begin{array}{l}\text { Stable in } \\
\text { cold, pos- } \\
\text { sibly stable } \\
\text { when hot. }\end{array}$ & $\begin{array}{l}\text { Slowly destroyed } \\
\text { in cold. Rapidly } \\
\text { destroyed when } \\
\text { hot. }\end{array}$ & $\begin{array}{l}\text { Rapidly destroyed } \\
\text { even when cold. }\end{array}$ \\
\hline $\begin{array}{l}\text { Stability to } \\
\text { acids. }\end{array}$ & 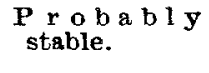 & $\begin{array}{l}\text { Comparatively } \\
\text { stable. }\end{array}$ & $\begin{array}{r}\text { Comparatively } \\
\text { stablebelow } 50^{\circ} \mathrm{C} \text {. }\end{array}$ \\
\hline
\end{tabular}

TABLE II.-Distribution of Accessory Factors in Natural Foodstuffs.

$\mathbf{A}=$ "Fat-soluble A." $\mathbf{B}=$ "Water-soluble B," or anti-beri-beri factor. $\mathbf{C}=$ "Water-soluble C," or antiscorbutic factor.

\begin{tabular}{|c|c|c|c|c|c|c|c|}
\hline Foodstuff. & A & $\mathbf{B}$ & $\mathbf{C}$ & Fondstuff. & A & B & C \\
\hline$\ldots$ & ++ & ++ & r & heat, whole \} & + & ++1 & - \\
\hline $\begin{array}{lll}\text { Butter } & \ldots & \ldots \\
\text { Oream } & \ldots . & \ldots\end{array}$ & $\begin{array}{c}+++ \\
+t\end{array}$ & + & $\bar{t} ?$ & ryo & ++ & $t+t$ & - \\
\hline Separated milik & 1.1 & ++ & + & $\mathrm{Wh}$ & - & - & - \\
\hline$\cdots$ & +++ & $\stackrel{+}{+}$ & & $\begin{array}{l}\text { sperm } \\
\text { wheat, bran }\end{array}$ & - & + & - \\
\hline$\ldots$ & 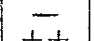 & + & $?$ & ili & $\bar{I}$ & & \\
\hline & & - & - & da... & \pm & ++ & $\Xi$ \\
\hline le oils & - & - & 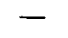 & eal? & + & $+t$ & \\
\hline $\left.\begin{array}{r}\text { fat, } \\
\text { arines }\end{array}\right\}$ & + & 一 & - & d...' & $+?$ & $+t+$ & -1 \\
\hline Vegetable oil, & - & -1 & - & act $\}$ & - & +++ & \\
\hline ean & & & + & Cabbage, fresh & ++ & + & $+f$ \\
\hline $\begin{array}{l}\text { Live } \\
\text { Heal }\end{array}$ & ++ & + & & $\ddot{~ d r i e d ~}$ & & $t$ & \\
\hline $\begin{array}{l}\text { Heart, kidn } \\
\text { Pancreas }\end{array}$ & & & & $\begin{array}{l}\text { no } \\
\text { es }\end{array}$ & +7 & + & \\
\hline Brail & + & +1 & & & - & - & \\
\hline "Let & 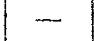 & t & + & \begin{tabular}{|cc} 
Tomatoes & $\ldots$ \\
Onions ...
\end{tabular} & $?$ & \pm & \\
\hline - Fat fish- & & + & & (green) & $\stackrel{3}{i}$ & - & \\
\hline $\begin{array}{l}\text { A.g., herming } \\
\text { Fish roe }\end{array}$ & & $+t$ & & $\begin{array}{l}\text { Lettuces } \\
\text { Peas, dry }\end{array}$ & + & - & - \\
\hline $\begin{array}{l}\text { Cod-liver ofl } \\
\text { Fish-body oils }\end{array}$ & $\begin{array}{l}+++ \\
++\end{array}$ & & 三 & Mält fresh .... & + & 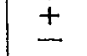 & ++ \\
\hline & & & & & & & \\
\hline
\end{tabular}

A rough attempt has been made to give some idea of the relative values of foodstuffe containing the factors by employing more than one positive sign. A negative sign indicates the absence of a factor, whilst an interrogation mark shows either a doubtful result or that no investigation has been made.

During the last few years I have carried out a large amount of experimental research on the influence of accessory substances upon the nutrition of young growing animals. For these experiments I have employed the rat, an animal which has many times been proved to be of the greatest value for such a purpose. The results I have obtained may have, I believe, in many cases an important bearing upon child nutrition, and for that reason I am putting forward certain suggestions, based upon practical 
experience, which I trust will engage the attention of those who possess a wide knowledge of the practical side of infant feeding.

These experiments upon animals have demonstrated the absolute indispensability of an adequate supply of the accessory factors during the period of growth. Since there is a certain amount of evidence in favour of the view that these substances are quantitatively utilised during tissue formation, it follows that the demand for them will be greatest during the period of most rapid growth that is, during very early life. ${ }^{3}$

What I wish to emphasise with all possible force is that the food-supply need not be entirely deficient in a factor such as these in order to bring about nutritive failure. A very slight inadequacy operating over a considerable period may be the cause of an apparently insignificant, but in reality very serious, disturbance of the health of the growing child, the effects of which may be marked long after the deficiency has been corrected.

\section{Breast Feeding.}

Experimental research has recently shown that the nursing mother is dependent upon her food-supply in order to provide her young with the accessory factors. Physiological evolution has elaborated a wonderful mechanism whereby the composition of the milk is, as far as possible, protected against the effects of dietary restrictions. But this protective process does not appear to extend to the accessory factors. Sacrifice of the mother's own tissues will frequently tide over a period of dietary deficiency as regards protein or energy intake, but only in the case of the "fatsoluble A" can she indirectly make good an inadequacy of accessory factors, and then only to the extent of calling up any reserves of that factor which she may possess. It should, therefore, be appreciated how vitally important is the necessity for an adequate supply of the accessory factors in the dietaries of expectant or nursing mothers. In fact, I go as far as to say that public authorities should emphasise this point with as much vigour as they do the importance of breast-feeding.

If the mother does not receive an adequate supply of these substances two results follow. First, what she does receive probably goes into her milk, for physiological evolution undoubtedly demands development of the child even at the expense of the mother, therefore she herself suffers the effects of a very serious deficiency; and, secondly, the young, in spite of the maternal sacrifice, receive an insufficient amount of the factor for normal nutrition.

This point may be illustrated by the following experimental results obtained with rats.

A young adult female rat was placed upon a diet seriously deficient in "fat-soluble A " as soon as it was observed that she was pregnant. Eight young of normal weight were subsequently born, of $\mathrm{w}$ hich four were destroyed to reduce the task of rearing. For over a fortnight the surviving soung grew at a normal rate, during which time it is surmised that the mother was correcting the dietary inadequacy by drawing upon her own reserves of the factor, but they then began to show signs of failing health. The rate of growth declined and both they and their mother showed great susceptibility to infection, particularly a form of external eye disease which will be deseribed subsequently. Two of the young died 31 days after birth from pyogenic infections, and both the mother and the surviving young were then given a normal dietary. One of the young failed to recover, having lost the sight of both eyes and contracted an infection of the lungs, but the mother and the remaining youngster survived and slowly regained their health. After 40 days from birth the voung rat appeared normal, and resumed a normal rate of growth upon the adequate ration.

Such a case is typical of a very large number, and exhibits what may be the consequences of a serious deficiency of one factor in the diet. It is improbable that deficiencies of so serious a nature would occur in this country, where even the poorest classes are able to obtain a mixed diet. On the other hand, there is considerable danger that the cost of the chief foodstuffs which serve as sources of the "fat-soluble A"milk, butter, and eggs-may result in a large number of mothers attempting to nurse their young whilst themselves receiving a dietary more or less inadequate in that factor.

I have carefully followed the results of feeding considerable numbers of rats upon such dietaries, and believe that they may serve to explain certain types of malnutrition so common in the lower classes. As described above, the young rats when born are usually of normal weight unlesw the mother has suffered from the restriction for some time previous to delivery, when, of course, her reserves may be already near exhaustion. They may also show throughout the period of dependence upon their mother a normal, or only slightly subnormal, rate of growth. But what is most important is that they never exhibit a normal standard of resistance to disease. Amongst rats this very frequently takes the form of a peculiar susceptibility to a characteristic form of external eye disease, which has been classified as a xerophthalmia.

The condition may be only slight if the dietary inadequacy of "fat-soluble $A$ " is also slight; but, on the other hand, it may be so severe as to involve the cornea and result in permanent blindness. I make the suggestion here that much of the low resistance to disease shown by the young of the poorer classes in this country is indirectly due not to any deficiency of protein or calories, but to their having received during a most critical period of their development an inadeqate supply of one or more of the indispensable accessory factors.

Fortunately our varied dietary in this country precludes any great danger from a deficiency of the "water-soluble $B$," and we need therefore not fear the incidence of conditions as severe as infantile beri-beri. Nevertheless, we should therefore take due precautions to ensure an adequate supply of this factor to the nursing mother.

Equally important is the necessity of providing the suckling child indirectly through the diet of the mother with a sufficiency of the antiscorbutic factor. I have not been able to work this point out experimentally, as the rat shows an extraordinarily low susceptibility to scurvy. This, however, is not so with the human infant, and we must remember that serious damage to health, perhaps with lifelong effects, may result from a failure to supply the child with an adequate amount of this substance, although it may be receiving sufficient to prevent the incidence of the typical syndrome of scurvy.

\section{Feeding with C'ow's Milk or Modified Milk.}

Since the rate of growth of the calf is greater than that of the child we have a certain amount of right to assume that cow's milk is an adequate source of the accessory factors for the growing human infant. This assumption appears to be supported by the fact that children can in certain cases thrive from a very early age on unmodified cow's milk. Perhaps, in such cases, it is wise to guard against a possible deficiency of the factor "O" by occasional administrations of orange juice, ${ }^{5}$ for the cow probably represents a species with a low susceptibility to scurvy, and therefore its milk contains little of the antiscorbutic substance.

The modification of cow's milk for infant feeding is a most important problem. In the past pediatricians have had as their aim the preparation of a fluid resembling human milk in its gross composition, and they have therefore made their calculations solely in terms of protein, fat, carbohydrate, and inorganic salts. Such a basis must now be discarded in favour of one which takes full account of the important accessory factors which we have described. If the modification of cow's milk is carried out only with products derived from milk there is little danger that a foodstuff deficient in the growth factors will be obtained. It should therefore be impressed upon all who have to carry out the modification of milk that true success will only be achieved by the employment of such units as cream and whey.

Too little attention is frequently paid to the source of fat used in modifying milk. For instance, one widely adopted substitute for cream is what has been termed "Marylebone cream," a preparation which is in reality an emulsion of linseed oil. This is added to a separated milk product and must therefore result in the production of a foodstuff very seriously deficient in "fat-soluble A," for it has been shown that vegetable oils do not contain this factor. ${ }^{6}$ Olive oil. another oil inadequate in this respect, is also employed to no inconsiderable extent for a similar purpose." I have no knowledge what results have been obtained in the feeding of infants with such preparations, but from my experience with animals fed on food mixtures showing the same deficiency I believe it will be found that such children will show a seriously diminished resistance to disease in spite of their having, perhaps, shown a normal development. 
Dried and Condensed Milk.

Dried milk is employed very extensively at the present time in infant feeding, and from the very fact that such excellent results are being obtained it appears that the accessory factors which influence growth are being supplied in a sufficient amount. The majority of dried milk is prepared by one or other of two processes, which we may term the "drum" and the "spray" processes respectively. In the former the exposure to a high temperature is probably insufficient to cause any appreciable destruction of factors " A" and " B," but it appears that the antiscorbutic principle may suffer. In the spraying processes, however, the dried milk powder remains in the chamber heated by a current of air at $115^{\circ} \mathrm{C}$., presumably until sufficient material has been collected. If this period extends over an hour or two a certain amount of destruction of the water-soluble growth factor may be caused. The majority of condensed milks are prepared by processes which should effect a very inappreciable destruction of the factor "B," and unsweetened condensed whole milk should, when carefully diluted, be an adequate source of the two growth factors "A " and "B." There is, however, very considerable danger in the employment of the other forms of condensed milk. The use of these products is discouraged on the ground that they are, when diluted according to the directions given on the package, seriously deficient in fat for infant feeding. We are here faced by a very important problem. Characteristic symptoms of malnutrition have often been described as following the use of fat-deficient infant foods, and it is most interesting that these symptoms are closely similar to those which are now associated with a deficiency of the indispensable "fatsoluble A." We may therefore ask whether a deficiency of fat is in itself a serious matter for the infant, or whether nutritive failure does not rather result from a restricted supply of the accompanying accessory factor. Personally, I believe the latter view is correct, and that mere corrections of the fat deficiency by the addition of a fat which does not contain the accesssory would effect little, if any, improvement in the health of the child, whereas the employment of an adequate fat, such as butter or cod-liver oil, would at once restore the subject to health. I put forward this suggestion purely as a result of experimental work with rats, and hope that those who make an extensive study of the subject of the artificial feeding of infants will give it some attention.

Propristary Infants' Foods.

These substitutes for mothers' milk must from their composition in many cases be seriously deficient in both accessory factors "A" and "B," but particularly in the former. Many of them are fat-deficient, and therefore equally deficient in the indispensable accompaniment to milk fat. Here again we may have a partial explanation of the characteristic liability to infection which is so frequently shown by the fat but pasty baby reared upon this type of food. Such dietaries should be adequately supplemented with rich sources of this factor in the form of cream or cod-liver oil, otherwise malnutrition will inevitably follow.

I have not touched on the important subject of infant scurvy because my experimental work with rats has given me no opportunity of studying that deficiency disease. This aspect of the problem has, however, been very fully treated by other workers in a previous paper which appeared in THE LANCET. ${ }^{5}$

It now remains for the practical worker on infant nutrition to apply the results of these experimental studies as soon as he is convinced of their accuracy.

References.-1. F. G. Hopkins: J. Physiol, 1912, xliv., 425. 2. J. C. Drummond: Biochem. J., 1917, xi., 255. 3. J.' C. Drummond : Biochem J., 1918, xi1., 25 4. E.V. Mccollum, N. Simmonds, and W. Pitz: J. Biol. Chem, 19i6, xxvii., 33. 5 H. Chick, E. M. Hume, and R. F Skelton, THE LANCET, Jan. 5th, 1918. 6. W. D. Halliburton and J. C. Drummond, J. Physiol., 1917, li., 235.

ROYAT SANITARY INSTITOTE.-A visit has been arranged to Messrs. Pilkington's Tile and Pottery Co.'s Factory, Clifton Junction, at 2 P.M., on Friday, Oct. 18th and at 6.30 P.M. a discussion will take place at the College of Technology, Manchester, on "Welfare Work in Factories and Workshops," to be opened by Professor J. Radcliffe, M.Sc.Tech., and Miss Ethel Brown (welfare secretary to Messrs. John Bright and Brothers, of Rochdale). The chair will be taken by Dr. Philip Boobbyer. Tickets from the secretary of the Institute, 90, Buckingham Palace-road, London, S.W. 1 .

\section{PROPHYLACTIC VACCINATIONS}

\section{AGAINST CATARRHAL AFFECTIONS OF THE RESPIRATORY TRACT.}

BY JOHN W. H. EYRE, M.D. DURH.,

BIRECTOR OF THE BACTERIOLOGICAI DEPARTMENT, GUY'S HOSPITAL; AND

C. E. LOWE, M.D.,

CAPTAIN, N.z.E.F.; PATHOLOGIST TO THE N.Z. GENERAI HOSPITAL, WALTON-ON-THAMES.

AMONGST those who are in the habit of employing vaccines therapeutically in civilian practice the impression has steadily gained ground that sufferers from catarrhal conditions of the respiratory tract are benefited by inoculations prophylactically administered. So far as we know, however, there have never been recorded any extended observations bearing upon the immunity obtained by the ordinary soldier from the prophylactic use of " mixed" vaccine against respiratory catarrh, although Wright ${ }^{1}$ and Lister ${ }^{2}$ employed pneumococcus vaccines for the prevention of pneumonia in the South African miner and Cecil and Austin ${ }^{3}$ used similar vaccires for the protection of the American soldier.

As we have recently had the opportunity of carrying out such a series of inoculations, on a scale which permitted the observation of a nominal roll of 1000 , we believe it might be of interest to record our results.

Outbreak of Measles and Rubella Complicated by "Purulent Bronohitis."

During January, 1918, 327 cases of measles and rubella, all of a mild type, were admitted to hospital from a certain camp occupied by the $n$-th Reinforcement of the New Zealand Expeditionary Force, which had arrived in England on the 7 th and 9 th of the month. During February a further 124 cases were admitted, and of these 24 died.

In consequence of this heary mortality one of the present writers was detailed, together with Lieutenant-Colonel H. French, R.A.M.C., consulting physician to the Aldershot Command, to investigate the outbreak. In all some 33 cases were inspected, and it at once became apparent that the exanthem was usually complicated by " purulent bronchitis" identical in its clinical features with the outbreak of purnlent bronchitis investigated by the same observers in the Aldershot Command during the early part of 1917-that is to say, apart from the rash of the primary measles or rubella, often very indistinct and atypical, the physical signs were insigniticant, usually only a few scattered rhonchi, but in all the sputum was abundant, consisting of pure pus. in most instances greenish-yellow, but in two cases reddened by altered blood. In the recent and severe cases cyanosis was pronounced, although the patients were lying flat and not in great distress.

Fourteen cases were selected for detailed bacteriological examination. Of these, three died, and observations were made on the post-mortem material thus rendered available. An autopsy was also made upon an Imperial officer from the same area, who-unconnected in any way with the N.Z.E.F. -had died from purulent bronchitis uncomplicated by any exanthem.

Speaking generally, the bacteriological findings were very similar. $B$. influenza was present on one or more occasions in 12 of the 14 sputa examined, usually associated with Strepto. cocous longus and various types of Microoocous oatarrhalis. In the fatal cases the heart blood and spleen showed the presence of Streptococous pyogenes longus with marked hrmolytic properties. Thus the analogy with the cases of purulent bronchitis observed the preceding year ${ }^{4}$ was complete; there was evidence of a primary infection of the respiratory tract by Bavillus infuenze, which so lowered the resistance of the individual that secondary infection by the Streptococeus pyogenes longus (and not the pneumococcus, as in the Aldershot epidemic) ensued, and in many instances resulted in an acute and rapidly fatal streptococcic septicæmia.

\footnotetext{
1 THE LAXCKT, 1914, 1., 87.

2 Publications of the South African Institute for Medical Research, 1916, No. 8, and 1917, No. 10. 3 Journal of Experimental Medicine, 1918, xxviil., 19

4 Purulent Bronchitis. By Abrahams, Hallows, Byre, and French, The Lax CET, Sept. 8th, 1917, p. 377.
} 